\title{
Analisis Perkembangan Harga Protein Hewani Asal Ternak dan Bahan Pakan Ternak di Kota Padang Tahun 2012
}

\section{Price Trend Analysis of Animal Protein and Raw Materials of Livestock Feed in Padang 2012}

\author{
W. Sartika dan E. Rahmi \\ Fakultas Peternakan Universitas Andalas \\ Kampus Unand Limau Manis Padang \\ Email : winda_pdg@yahoo.com \\ (Diterima : 30 April 2014, Disetujui : 1 September 2014)
}

\begin{abstract}
ABSTRAK
Penelitian ini dilakukan untuk mengetahui perkembangan harga protein hewani asal ternak khususnya daging, telur, susu serta bahan pakan ternak di Kota Padang tahun 2012. Metode penelitian adalah studi literatur tentang data bulanan harga protein hewani tahun 2012. Analisis data disajikan secara deskriptif kualitatif. Hasil penelitian menunjukkan perkembangan harga protein hewani di Kota Padang tahun 2012 untuk harga daging sapi mengalami kenaikan harga tertinggi pada bulan September sebesar 9\% jika dibandingkan dengan harga daging sapi pada Agustus 2012 yaitu Rp78000/kg. Harga daging kambing atau domba mengalami penurunan sebesar 33\% pada bulan Maret ke April 2012. Harga telur ayam ras dan telur puyuh cukup stabil dengan harga rata-rata untuk ayam ras sebesar Rp 1.050/butir dan telur puyuh Rp 283/butir. Harga bahan baku pakan khususnya jagung mengalami fluktuasi sejak bulan Januari sampai dengan Desember 2012 sedangkan harga dedak sebesar Rp 2.500/kg stabil sampai akhir tahun 2012.
\end{abstract}

Kata kunci : harga, protein hewani, pakan ternak

\section{ABSTRACT}

A study was conducted to analyze the price trend of both animal products such as egg, meat, milk and raw materials of livestock feed in Padang City 2012. Procedure of literature study used to collect secondary data on the price of animal protein and raw materials of feed on the month by month basis in 2012. The collected data were analyzed by both descriptive and qualitative approaches. The results showed that there was a tendency of increasing on animal protein price at Padang in 2012. The highest price of beef was in September where there was a 9\% increase compared to August (Rp $78000 / \mathrm{kg}$ ). However, the price of goat meat and lamb tend to be decreased by $33 \%$ in Mart to April 2012. Eggs price for layer and quail were fairly stable at an average of Rp 1.050/egg for layer and Rp 283/egg for quail. Corn price fluctuated from January to December 2012 while the price of rice bran was consistent at Rp 2.500/kg until the end of the year.

Key words : price, animal protein, feed

\section{PENDAHULUAN}

Sumatera Barat merupakan salah satu kawasan agribisnis peternakan yang mempunyai prospek cukup baik untuk terus dikembangkan. Beraneka ragam ternak besar dan kecil ada di Sumatera Barat seperti ternak sapi potong, kerbau, kambing, sapi perah, itik dan lain-lain. Selain itu usaha penunjang komoditi peternakan seperti pabrik pakan dan rumah potong hewan juga sudah ada di Sumatera Barat.

Kota Padang sebagai ibu kota Provinsi Sumatera Barat juga mempunyai prospek peternakan yang cukup baik untuk dikembangkan. Berbagai masalah yang timbul pada usaha peternakan biasanya dikarenakan ketidakseimbangan antara input dan output yang dihasilkan. Salah satu penyebab ketidakstabilan penerimaan peternak adalah harga 
jual produk hasil ternak dengan biaya input yang dikeluarkan.

Harga merupakan salah satu indikator penentu dalam setiap transaksi perdagangan yang dilakukan. Harga juga dapat membuat para pengusaha atau peternak menjadi untung ataupun merugi. Harga bahan makanan sumber protein hewani seperti daging, telur dan susu relatif lebih mahal dibandingkan dengan harga sumber protein nabati, walaupun demikian ternyata terjadi peningkatan pada konsumsi hewani. Hal ini disebabkan oleh meningkatnya pengetahuan masyarakat akan gizi serta kualitas protein (Setiawan, 2006).

Harga komoditi peternakan baik daging, telur ataupun susu di setiap daerah sangat bervariasi. di Kota Padang harga protein hewani seperti daging cenderung meningkat setiap tahun karena pengaruh permintaan daging yang tinggi oleh masyarakat. Sedangkan untuk harga bahan pakan ternak seperti jagung cenderung tidak stabil. Saat ini harga jagung merupakan masalah utama bagi para peternak ayam ras selain itu harganya juga tidak stabil dan cenderung selalu meningkat. Tingginya harga jagung dapat disebabkan oleh jumlah permintaan yang tinggi sedangkan stok jagung yang ada tidak mencukupi. Saat ini jagung sebagai pakan ternak sebagian besar masih berasal dari luar Kota Padang ataupun Sumatera Barat.

Tingginya kebutuhan dan tuntutan akan informasi pasar pertanian khususnya sektor peternakan yang meliputi harga, jumlah kualitas penawaran serta permintaan produk oleh pelaku agribibisnis mulai dari tingkat petani sampai konsumen sangat dibutuhkan oleh masyarakat. Dinamika harga komoditas peternakan dapat berubah setiap saat seiring dengan perbedaan ruang dan waktu. Tidak stabilnya harga jagung berdampak besar pada harga ouput yang dihasilkan ternak tersebut seperti telur dan daging ayam broiler. Untuk lebih memahami seberapa besar perubahan harga output masing-masing komoditi peternakan sebagai sumber protein hewani dan bahan baku pakannya maka peneliti tertarik untuk melakukan penelitian dengan judul Analisis Perkembangan Harga Protein Hewani Asal
Ternak dan Bahan Baku Pakan Ternak di Kota Padang Tahun 2012.

\section{METODE}

Penelitian ini dilakukan di Kota Padang. Data yang digunakan pada penelitian ini merupakan data sekunder yang berasal dari database Dinas Peternakan Provinsi Sumatera Barat dan data dari Badan Pusat Statistik pada tahun 2012. Metode yang digunakan memakai pendekatan penelaahan data sekunder dan analisis statistik deskriptif dengan bantuan grafik.

\section{HASIL DAN PEMBAHASAN}

Peningkatan populasi penduduk dan perbaikan taraf hidup masyarakat menyebabkan permintaan terhadap berbagai kebutuhan bahan pangan terus meningkat. Pola konsumsi menu makanan rumah tangga juga secara bertahap mengalami perubahan kearah peningkatan konsumsi protein hewani termasuk produk peternakan (Hadini, et al., 2011). Harga merupakan salah satu hal yang menjadi pertimbangan saat masyarakat akan membeli barang yang akan mereka konsumsi. Perkembangan harga untuk produk-produk hasil ternak cenderung bersifat fluktuatif dikarenakan sifatnya yang musiman dan mudah rusak. Selain itu harga bahan baku input ternak yang tidak stabil juga sering mendorong untuk terjadinya kenaikan harga protein hewani. Gambar 1. Menjelaskan bahwa harga daging ayam broiler cenderung stabil pada tahun 2012 dan sedikit mengalami kenaikan pada saat bulan Agustus 2012. Harga rata-rata protein hewani untuk daging ayam broiler pada tahun 2012 adalah sebesar $\mathrm{Rp} 18.600 / \mathrm{kg}$.

Harga daging sapi cenderung mengalami kenaikan pada tahun 2012 sebesar 3\% sampai 9\% dengan harga daging sapi berkisar antara Rp70.000,00/kg Rp 80.000,00/kg. Kenaikan tertinggi untuk harga daging sapi terjadi pada saat bulan September 2012 dikarenakan masyarakat merayakan Hari Lebaran. Berdasarkan budaya dan rasa, posisi daging sapi tidak dapat digantikan dengan daging lainnya. 


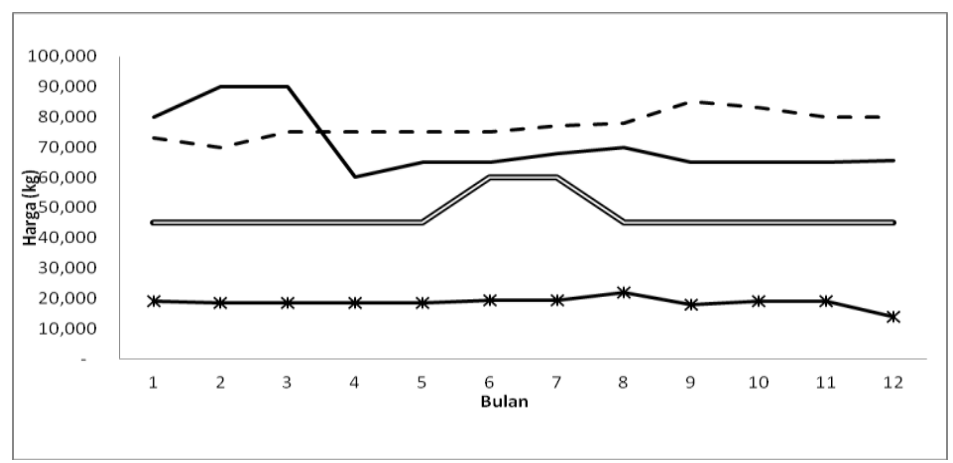

Gambar 1. Perkembangan Harga Protein Hewani di Kota Padang Tahun 2012

Ket : -*- daging broiler $(\mathrm{kg})$, - - -daging sapi $(\mathrm{kg})$,_ daging kambing $(\mathrm{kg}),==$ daging babi $(\mathrm{kg})$

Menurut Ilham (2009), ketersediaan daging sapi selalu dibutuhkan baik pada masyarakat berpendapatan tinggi, sedang maupun rendah. Perilaku tersebut menyebabkan harga daging sapi terus meningkat.

Sedangkan harga daging kambing atau domba mengalami penurunan sebesar $33 \%$ pada bulan Maret ke April 2012. Hal ini bisa disebabkan karena rendahnya permintaan terhadap ternak kambing atau domba oleh masyarakat sedangkan jumlah ternak kambing yang dipelihara cukup banyak.

Telur ayam dan telur itik adalah dua produk peternakan yang paling banyak diserap oleh pasar. Kebutuhan masyarakat akan telur setiap tahun mengalami peningkatan (Rahardi dan Hartono, 2003). Pada Gambar 2. Menjelaskan tentang kondisi harga protein hewani asal telur (ayam ras, ayam buras, itik dan telur puyuh) selama tahun 2012 di Kota Padang. Terlihat bahwa harga telur ayam ras dan harga telur puyuh stabil dengan harga rata-rata $\mathrm{Rp}$ $1.000,00 /$ butir untuk telur ayam ras dan $\mathrm{Rp}$ 283,00/butir untuk telur puyuh. Fluktuasi harga telur terjadi untuk telur ayam buras dan telur itik yaitu terlihat pada awal tahun 2012 (bulan Januari) harga telur ayam ras adalah Rp 1.800,00/butir dan pada akhir tahun 2012 harganya mengalami kenaikan menjadi Rp2.000,00/butir atau meningkat sebesar $10 \%$ di akhir tahun 2012.

Telur itik juga mengalami kenaikan dari harga Rp 2.000,00/butir menjadi Rp 2.500,00/butir diakhir tahun 2012 atau meningkat sebesar 25\% dibandingkan dengan harga telur itik pada bulan Januari 2012. Kenaikan harga protein hewani ini tidak hanya dipengaruhi oleh permintaan akan barang tersebut tetapi dapat juga dipengaruhi oleh harga barang-barang substitusinya.

Pakan merupakan kebutuhan utama dari ternak. Pada ternak puyuh biaya pakan bisa mencapai $80 \%$ dari total biaya produksi yang dikeluarkan (Wuryadi, 2011). Pakan utama untuk ternak ayam adalah jagung dan dedak. Semakin tinggi harga jagung di pasaran akan berdampak pada harga telur yang akan diterima oleh konsumen. Pada tahun 2012 harga jagung pipil rata-rata $\mathrm{Rp} 3.875,00 / \mathrm{kg}$, harga rata-rata jagung giling $\mathrm{Rp} 3.783,00 / \mathrm{kg}$ dan harga dedak rata-rata adalah Rp2.500,00/kg.

Pada Gambar 3, terlihat bahwa harga jagung pipil dan harga jagung giling sangat fluktuatif. Hal ini dikarenakan kebutuhan jagung yang semakin tinggi sedangkan jumlah ketersediaan jagung semakin sedikit. Jumlah pakan yang diberikan harus tepat waktu dan jumlah. Jagung adalah bahan pakan yang paling banyak digunakan dalam industri pakan ternak. Jagung merupakan bahan pakan sumber energi bagi ternak selain dedak. Tetapi kadar proteinnya lebih tinggi bila dibandingkan dedak (Wuryadi, 2011).

Tingginya harga pakan telah mengakibatkan biaya produksi ternak tinggi khususnya ternak unggas. Untuk itu diperlukan upaya agar penggunaan pakan yang ada lebih efektif dan efisien. 


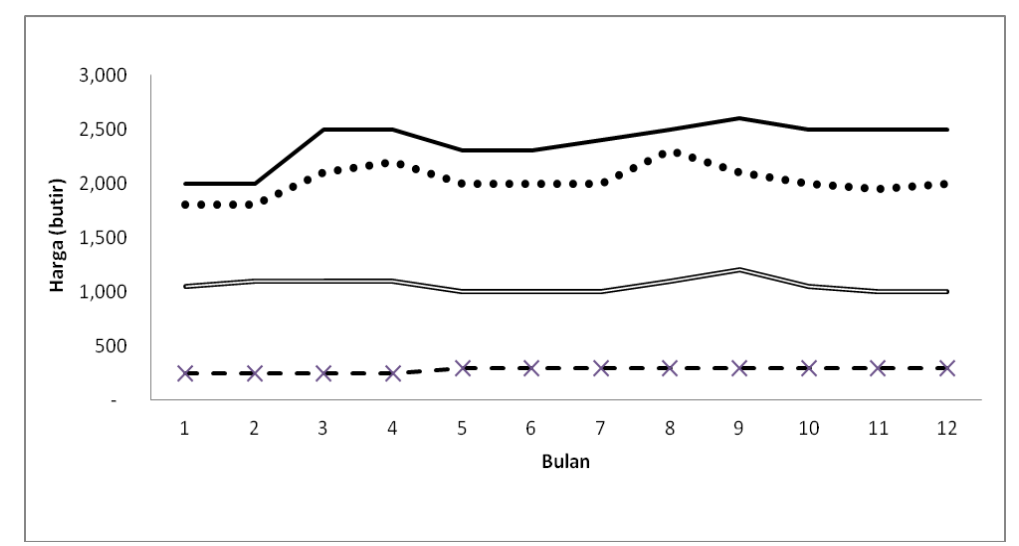

Gambar 2. Perkembangan Harga Telur di KotaPadang Tahun 2012

( Ket : == telur ayam ras, .... telur ayam kampung, — telur itik, - - - telur puyuh)

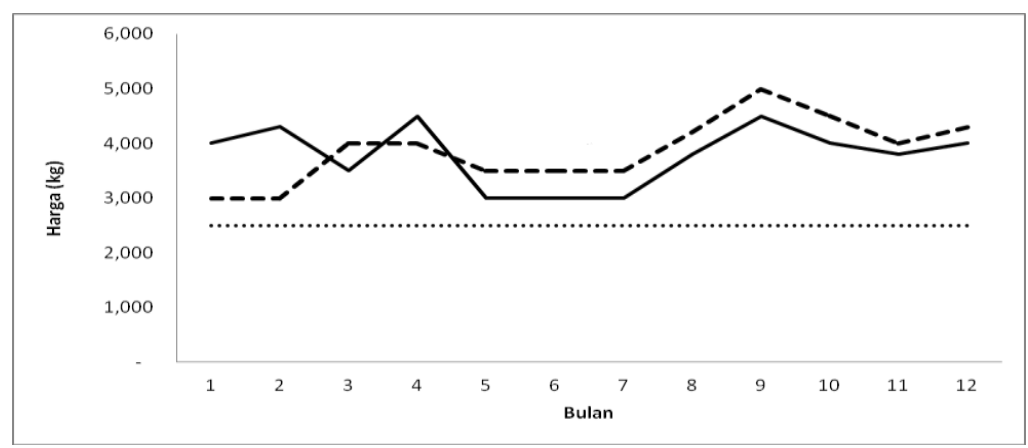

Gambar 3. Perkembangan Harga Pakan Ternak Unggas di Kota Padang Tahun 2012 ( Ket : --- jagung pipil, —— jagung giling, ..... dedak)

Bahan pakan ternak ayam yang biasa digunakan adalah jagung dan dedak sebagai bahan penyusun ransum, sumber energi dan sebagai sumber karbohidrat serta dapat tersedia sepanjang tahun. Jagung dan dedak padi merupakan pakan utama yang digunakan untuk ayam broiler (Sari dan Gurki, 2012).

Pada ternak sapi bahan pakan yang biasanya digunakan berupa hijauan dan pakan konsentrat. Seiring dengan semakin tingginya harga konsentrat dan keterbatasan lahan untuk menanam hijauan pakan ternak maka pakan alternatif sering digunakan oleh para peternak. Salah satu pakan alternatif yang digunakan berasal dari limbah pertanian seperti jerami.

Pemanfaatan limbah pertanian sebagai pakan ternak ruminansia telah dikenal luas, hal ini dikarenakan kemampuan ternak ruminansia mengkonversi bahan pakan yang mengandung serat kasar menjadi produk- produk yang bermanfaat untuk pertumbuhan dan reproduksi ternak ruminansia. Jerami padi merupakan salah satu limbah pertanian yang tersedia melimpah sepanjang tahun, namun kualitas jerami padi adalah sangat rendah karena tingginya kadar serat kasar. (Sumadi, 2010). Saat ini limbah tanaman jagung juga sudah mulai digunakan sebagai pakan alternatif bagi ternak ruminansia, menurut Umiyasih dan Wina (2008), limbah tanaman jagung dan agroindustrinya cukup potensial sebagai pakan termak ruminansia. Namun karena nilai nutrisi yang terkandung didalamnya pada umumnya rendah dan sebaiknya dikombinasikan dengan bahan pakan lain sebagai sumber protein.

\section{KESIMPULAN}

Perkembangan protein hewani asal ternak selama tahun 2012 mengalami fluktuasi harga pada daging sapi, daging ayam ras, telur 
ayam ras dan telur ayam kampung. Kenaikan juga terlihat pada harga bahan baku pakan utama ternak ayam yaitu jagung. Selama tahun 2012 harga jagung terus mengalami fluktuasi.

\section{DAFTAR PUSTAKA}

Hadini. H.A, S. Nurtini, dan E. Sulastri. 2011. Analisis permintaan dan prediksi konsumsi daging broiler di Kota Kendari propinsi sumawesi Tenggara. Buletin Peternakan 35 (3) : 202-207

Ilham, N. 2009. Kebijakan pengendalian harga daging sapi nasional . J.Analisis Kebijakan Pertanian. Vol.7 Edisi 3

Rahardi F dan Hartono R. 2003. Agribisnis Peternakan. Seri Agribisnis. Penebar Swadaya. Jakarta
Samadi, Yunasri U dan Mira D. 2010. Pakan ternak ruminansia di Kabupaten Aceh besar. J. Agripet, 10 (2) : 45-53

Sari, M.L dan Gurki N. G. 2012. Pengaruh penambahan enzim fitase pada ransum terhadap berat relatif organ pencernaan ayam broiler. J.Agripet : 12 (2) : 37-41

Setiawan N. 2006. Perkembangan konsumsi protein hewani di Indonesia : analisis hasil survey sosial ekonomi nasional 2002-2005. J. Ilmu Ternak, Juni 2006, $6(1): 68-74$

Umiyasih U dan Wina. 2008. Pengolahan dan nilai nutrisi limbah tanaman jagung sebagai pakan ternak ruminansia. Wartazoa, Buletin Ilmu Peternakan Indonesia, 2008, 18 (3) : 127-136

Wuryadi S. 2011. Buku Pintar Beternak dan Bisnis Puyuh. Agro Media Pustaka. Jakarta 